\section{Science appeal}

Walter Gratzer

They're Not Dumb, They're Different. Stalking the Second Tier. By Sheila Tobias. Research Corporation, 6840 East Broadway Boulevard, Tucson, Arizona 85710, USA: 1990. Pp.94. Distributed free.

IT was, I think, an aperçu of Adlai Stevenson's that American society could be spared an incalculable amount of pain and expense were every child invested at birth, as part of its inalienable patrimony, with a $\mathrm{BA}$ or BSc degree. The balance between the two could then be adjusted each year, according to the temper of the time. Such a disposition might go some way towards meeting the issues raised in Sheila Tobias's study, which is about why so many American university students forsake science for other disciplines and how to stop them.

Tobias's title begs a question or two to start with, for it carries the merest nuance of a hint that those who prefer Greek poetry or economics or (save the mark) sociology to science might be written off by many of us as intellectually inferior (even if Tobias knows they are not); and indeed that those who are not good at science really are inferior and thus fit only to become hairdressers, high-court judges or merchant bankers. It also implies, does it not, that more scientists are needed and that employment appropriate to their skills awaits them? This last premise receives a passing mention near the end of the report, but is not examined.

The remit of this study then is narrow. All the same, the results make compelling reading. Tobias's touch is deft and her style refreshingly free of jargon. Her conclusions are based on the outcome of an interesting experiment: seven students (one of them a middle-aged professor of classics), who had all taken an interest in science or mathematics at an early stage in their education, were invited to take a science course and report how they got on. All are thoughtful and articulate peopleseveral cuts, as I would judge, above the average undergraduate, and selected perhaps for that reason. Their verdicts on the merits of the several courses and on those who taught them show a striking unanimity. They found first a charged and competitive atmosphere in the classroom. Science students tended to regard their colleagues, and especially the brighter ones, as a threat; they showed none of the eager curiosity about their subjects that marked their coevals in the humanities. At the mention of any matters on which they were given to understand they would not be examined their eyes would glaze.

The presentation of the course material was held to be tedious, with an excessive emphasis, as Tobias's guinea pigs saw it, on "problem solving" - mastering, in other words, the techniques of the craft without reference to the purposes to which they might be put. "Too many scales, not enough music" is how Tobias sums it up. Yet this analogy brings to mind the story of how the celebrated singing teacher, Manuel Garcia, was supposed to have trained his students: for two years they were allowed to sing nothing but scales and arpeggios. Then came the moment when he would send the student on his way, with his blessing: "I have taught you all I know. Now learn some songs and operas and go into the world and make your fortune." I rather suspect that students intellectually and temperamentally drawn to science would be more likely to find satisfaction in mastering its basic grammar. One of the experimental subjects for example says of his chemistry course that more attention was paid to Avogadro's number than to Avogadro's insight. The implied plea for a more historically-minded approach to science teaching deserves to be taken seriously, but the antithesis is still a false one.

Further, the instructors were accused of having done nothing to encourage originality or audacity of thought. In short, they were failing to educate, for where they should have drawn out they sought only to bash in. Eric, one of the astutest of the seven students, gives this example: "we were to judge the best clock for timekeeping, given a record of five clocks' readings at exactly noon. The professor chose the clock that gained exactly 51 seconds every day. I picked the clock that was within seven seconds of noon day after day. A scientist wants predictability; I would rather have convenience." Of course the professor (or the student) might also have noted that a clock that has stopped is pretty good too, for it registers the right time twice a day, whereas one that loses seven seconds a day will be exact only once in about 17 years.

When a professor was taxed with the strictures of one of Tobias's students on the quality of his chemistry course, his riposte was: "It is dull. It is dull to learn and dull to teach. Unfortunately it is the basic nuts and bolts stuff that must be mastered before anything can be accomplished. ..."Well it is no great revelation that much (most?) university teaching is lustreless and perfunctory. Faculty members are mostly there, after all, because they want to do research; and insofar as they are willing to teach, they will invariably prefer, as at least one of Tobias's subjects also perceives, to occupy themselves with professors of the future (who, when their time comes, will aim to create yet more professors). But there is alas no seller's market in professors - and besides, embryo professors are the students least in need of teaching.

Tobias's investigation was spurred by

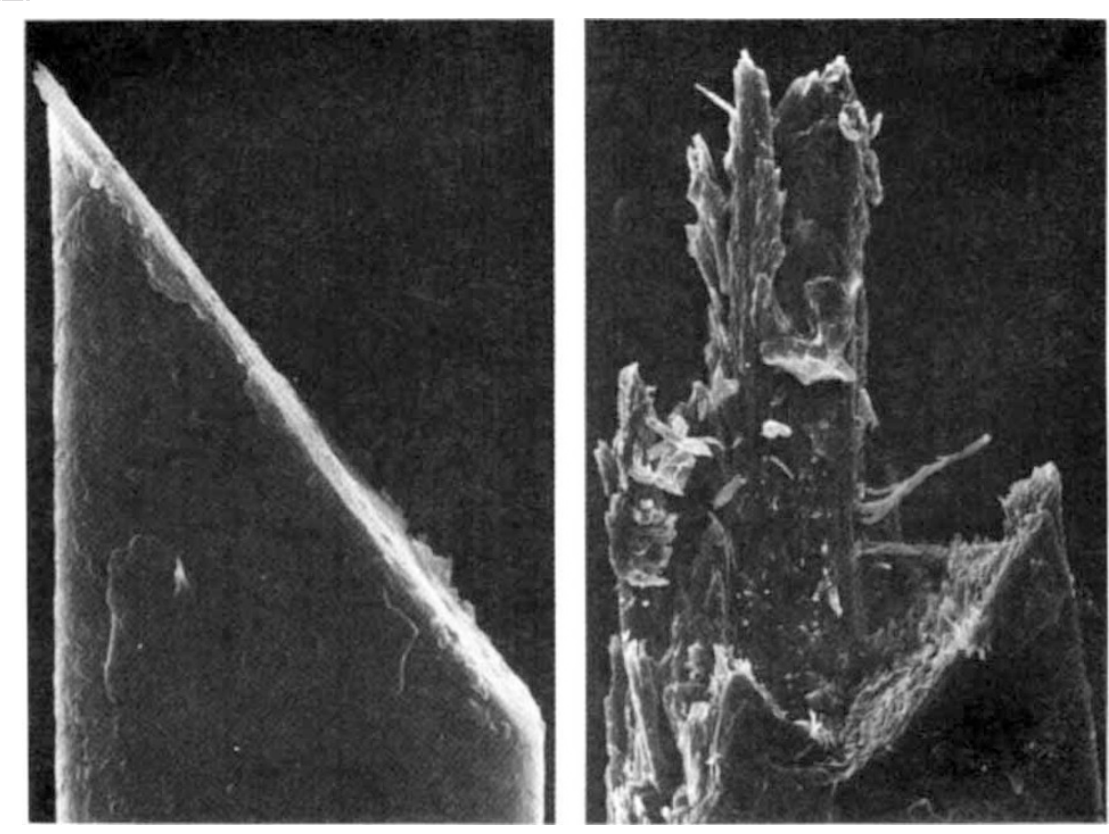

The scanning electron micrograph on the left is a man's beard hair, cleanly sliced by the blade of a 'wet' razor. On the right is a beard hair from the same man, torn by the action of an electric razor (both micrographs $\times 195$ ). These pictures from the new paperback edition of Under the Microscope: A Hidden World Revealed by J. Burgess, M. Marten and $\mathrm{R}$. Taylor, form part of an intriguing array of pictures representing the everyday world seen under close scrutiny. The human body, seed plants, inorganic world and industrial world are some of the areas that are explored. Informative captions accompany each picture and the volume ends with a useful technical appendix. Published by Cambridge University Press on 12 July, $£ 12.95, \$ 19.95$. 